\title{
Faktor-Faktor yang Mempengaruhi Kinerja Koperasi Syariah di Kabupaten Lombok Timur
}

\author{
Salmi Yuniar Bahri, Nova Hari Santhi \\ STIA Muhammadiyah Selong \\ salmijuniar@gmail.com, nharisanty@gmail.com
}

\begin{abstract}
Abstrak
Tujuan dari penelitian ini adalah untuk mengetahui faktor apa saja yang mempengaruhi kinerja koperasi syariah di Kabupaten Lombok Timur. Penelitian ini adalah metode deskriptif kuantitatif fokusnya adalah untuk membuat deskripsi gambaran atau lukisan secara sistematis, faktual dan akurat serta menjelaskan dan menganalisa kemudian menarik suatu kesimpulan dari hasil penelitian tentang faktor-fakto yang mempengaruhi kinerja koperasi syariah. Sampel dalam penelitian ini adalah seluruh koperasi syariah di Kabupaten Lombok Timur yang berjumlah 41 unit. Analisis data yang digunakan dalam penelitian ini adalah Regregi Linier Berganda. Analisis Regresi Linear Berganda digunakan untuk mengukur pengaruh antara lebih dari satu variabel prediktor (variabel bebas) terhadap variabel terikat, yang menjadi variabel terikat (kinerja koperasi syariah) sedangkan variabel bebas partisipasi, komitmen, Kemampuan Berinovasi). Hasil penelitian ini mengungkapkan bahwa terdapat pengaruh antara partispasi, komitmen, kemampuan berinovasi terhadap kinerja koperasi syariah.
\end{abstract}

Kata Kunci: Partisipasi, Komitmen, Kemampuan Berinovasi, Kinerja Koperasi

\begin{abstract}
The purpose of this study is to determine what factors affect the performance of sharia cooperatives in East Lombok regency. This research is descriptive kuantitatif method of focus is to make description of picture or painting systematically, factually and accurately and explain and analyze then draw a conclusion from result of research about factors influencing performance of sharia cooperative. The sample in this study is the entire sharia cooperative in East Lombok regency amounting to 41 units. The data analysis used in this research is Double Linear Regression. Multiple Linear Regression Analysis is used to measure the influence between more than one predictor variable (independent variable) to the dependent variable, the dependent variable (Sharia cooperative performance) while the independent variable Participation, Commitment, Innovation Ability). The results of this study revealed that there is influence between participation, commitment, and ability to innovate on the performance of sharia cooperatives.
\end{abstract}

Keywords: Participation, Commitment, Innovation Ability, Cooperative Performance 


\section{Pendahuluan}

Di dalam perekonomian untuk mensejahterakan masyarakat ada yang dinamakan dengan perusahaan atau badan usaha yang bergerak di dalam perkumpulan orang-orang disebut Koperasi. Di Indonesia koperasi pertama kali didirikan oleh Raden Aria Wiraatmadja, seorang patih dari Purwokerto, tahun 1896. Raden Aria Wiraatmadja bekerjasama dengan E. Sieburg mendirikan bank penolong dan tabungan yang dalam bahasa belanda disebut Hulep En Spaar Bank. Koperasi adalah badan usaha yang beranggotakan orang-seorang atau badan hukum Koperasi dengan melandaskan kegiatannya berdasarkan prinsip Koperasi sekaligus sebagai gerakan ekonomi rakyat yang berdasar atas asas kekeluargaan (Undang-Undang Koperasi No. 25 tahun 1992 pasal 1). Koperasi bertujuan memajukan kesejahteraan anggota pada khususnya dan masyarakat pada umumnya serta ikut membangun tatanan perekonomian nasional dalam rangka mewujudkan masyarakat yang maju, adil, dan makmur berlandaskan Pancasila dan Undang-Undang Dasar 1945 (Undang-Undang Koperasi No. 25 tahun 1992 Pasal 3).

Koperasi dibagi menjadi dua yaitu koperasi umum dan koperasi syariah, Perbedaannya terletak pada produk-produk yang ada di koperasi umum diganti dan disesuaikan nama dan sistemnya dengan tuntunan dan ajaran agama Islam. Koperasi Syariah juga memiliki pengertian dan peran yang sama dengan koperasi umum. Namun Koperasi syariah menggunakan konsep Syirkah Mufawadhoh yakni sebuah usaha yang didirikan secara bersama-sama oleh dua orang atau lebih, masing-masing memberikan konstribusi dana dalam porsi yang sama besar dan berpartisipasi dalam kerja. Maka masing-masing partner saling menanggung satu sama lain dalam hak dan kewajiban. Koperasi syariah bertujuan untuk meningkatkan kesejahteraan anggota pada khususnya dan masyarakat pada umumnya serta turut membangun tatanan perekonomian yang berkeadilan sesuai syariah Islam yaitu Al-qur'an san Assunnah (Arifin Sitio, 2001).

Perkembangan koperasi syariah di Indonesia mengalami peningkatan dari masa ke masa. koperasi syariah mulai booming seiring dengan perkembangan dunia industri syariah di Indonesia yang dimulai dari pendirian Bank Syariah pertama pada tahun1992. Secara umum koperasi syariah dinaungi oleh keputusan Menteri (Kepmen) Koperasi dan UKM Republik Indonesia Nomor 91 tahun 2004 Tentang Petunjuk Pelaksanaan Kegiatan Usaha Koperasi Jasa Keuangan Syariah. Kalau dilihat dari intensitasnya, pada tahun 2015 jumlah koperasi syariah di Kabupaten Lombok Timur yang aktif sebanyak 43 
unit dengan volume usahanya mencapai Rp.436.022, sedangkan pada tahun 2016 dengan jumlah koperasi syariah aktif 38 unit volume usaha menjadi Rp.425.133, penurunan jumlah koperasi syariah yang aktif merupakan bukti ketidak seriusan perangkat koperasi dalam mengelola koperasi syariah tersebut. Ketidak seriusan perangkat koperasi dikarenakan kurangnya pengetahuan tentang pembukuan yang menyebabkan tidak terselenggaranya RAT (Rapat Anggota Tahunan).

Sementara itu bagi koperasi yang tidak aktif yaitu sebanyak 2 unit pada posisi 2015 dan 3 unit pada posisi 2016, Dinas Perindustrian Perdagangan Koperasi dan UKM Lombok Timur akan selalu mendorong agar koperasi syariah bisa berkembang melalui dukungan sejumlah peraturan daerah dalam meningkatkan kinerja koperasi syariah. Banyak faktor yang mempengaruhi kinerja koperasi. Tambunan (2012) menyatakan bahwa koperasi dalam menjalankan kegiatannya sangat dipengaruhi baik oleh lingkungan internal (anggota, organisasi dan kelembagaan, manajemen, modal, kegiatan usaha, keangotaan, teknologi) maupun lingkungan eksternal (sosial, politik, informasi, perekonomian, hukum, dan sosial budaya) ditingkat regional, nasional dan internasional. Rumusan masalah dalam penelitian ini yaitu, faktor apa saja yang mempengaruhi kinerja koperasi syariah di Kabupaten Lombok Timur? Adapun tujuan penelitian ini yaitu, untuk mengetahui faktor apa saja yang mempengaruhi kinerja koperasi syariah di Kabupaten Lombok Timur?

Menurut Undang-Undang No. 12 tahun 1967 tentang pokok-pokok perkoperasian, koperasi Indonesia adalah organisasi ekonomi rakyat berwatak sosial, beranggotakan orang-orang atau badan hukum koperasi yang merupakan tata susunan ekonomi sebagai usaha bersama berdasar atas asas kekeluargaan. Menurut Undang- Undang No. 25 tahun 1992 tentang perkoperasian menyatakan bahwa, koperasi adalah badan usaha yang beranggotakan orang seorang atau badan hukum koperasi dengan melandaskan kegiatannya berdasarkan prinsip koperasi dan sekaligus sebagai gerakan ekonomi rakyat yang berdasar atas asas kekeluargaan.

Prinsip Koperasi berdasarkan UU No. 17 Th. 2012, yaitu: modal terdiri dari simpanan pokok dan Surat Modal Koperasi (SMK). Lebih detail tentang ketentuan pengaturan koperasi BMT diatur dengan Keputusan Menteri Koperasi Usaha Kecil dan Menengah No. 91 Tahun 2004 (Kepmen No. 91/KEP/M.KUKM/IX/2004). Dalam ketentuan ini koperasi BMT disebut sebagai Koperasi Jasa Keuangan Syariah (KJKS). 
Dengan ketentuan tersebut, maka BMT yang beroperasi secara sah di wilayah Republik Indonesia adalah BMT yang berbadan hukum koperasi yang izin operasionalnya dikeluarkan oleh Kementerian Koperasi dan Usaha Kecil dan Usaha Menengah atau departemen yang sama dimasing-masing wilayah kerjanya. Selain harus sesuai dengan Kepmen No. 91/Kep/M.KUKM/IX/2004 ini, koperasi BMT (KJKS) harus juga tunduk dengan koperasi yaitu Undang-Undang Nomor 25 Tahun 1992 tentang perkoperasian. Menurut pandangan ulama, koperasi (syirkah ta'uwuniyah) dalam Islam adalah menggunakan akad musyarakah, yakni suatu perjanjian kerja sama antara dua orang atau lebih, di satu pihak menyediakan modal usaha, sedangkan pihak lain melakukan usaha atas dasar profit sharing menurut perjanjian, dan di antara syarat sah musyarakah itu ialah keuntungan setiap tahun dengan persentase tetap kepada salah satu pihak dari musyarakah tersebut.

Kinerja adalah suatu tampilan keadaan secara utuh atas perusahaan selama periode waktu tertentu, merupakan hasil atau prestasi yang dipengaruhi oleh kegiatan operasional perusahaan dalam memanfaatkan sumber- sumber daya yang dimiliki (Helfert, 1996). Kinerja menurut Mulyadi (2001) adalah penentuan secara periodik efektivitas operasional organisasi, bagian organisasi dan karyawannya berdasarkan sasaran, standar dan kriteria yang telah ditetapkan sebelumnya. Jadi kinerja perusahaan merupakan sesuatu yangdihasilkan oleh suatu perusahaan dalam periode tertentu dengan mengacu pada standar yang ditetapkan. Sistem penilaian kinerja yang efektif sebaiknya mengandung indikator kinerja, yaitu: (1) memperhatikan setiap aktivitas organisasi dan menekankan pada perspektif pelanggan; (2) menilai setiap aktivitas dengan menggunakan alat ukur kinerja yang mengesankan pelanggan; (3) memperhatikan semua aspek aktivitas kinerja secara komprehensif yang mempengaruhi pelanggan, dan (4) menyediakan informasi berupa umpan balik untuk membantu anggota organisasi mengenali permasalahan dan peluang untuk melakukan perbaikan.

Partisipasi anggota merupakan kata kunci untuk menuju kesuksesan koperasi (Djamhari, 1985). Untuk itu pengembangan usaha koperasi diarahkan untuk pengembangan peran anggota. Menurut Hanel partisipasi anggota mempengaruhi keberhasilan koperasi (Alfres, 1985). Sedangkan Keberhasilan koperasi dapat di ukur dengan: pertumbuhan anggota, meningkatnya SHU dan meningkatnya permodalan koperasi (Azis, 1985: 320). Untuk menilai keberhasilan pengembangan organisasi 
koperasi yang dapat dijadikan tolak ukur: (1) efisien dalam pengelolaan; (2) efesien dalam pembangunan dan (3) efisien yang berorientasi pada anggota. Koperasi pondok pesantren sebagai badan usaha ekonomi dituntut untuk dapat mewujudkan suatu kesejahteraan ekonomi bagi pelaku- pelakunya, artinya pengurus dan badan pengawas harus mempunyai minat untuk mempergunakan kinerja pemikirannya dalam mengatasi permasalahan- permasalahan yang ada pada koperasi untuk memperkenalkan aktualisasi dan dinamisasi koperasi kepada anggota. Peran partisipasi aktif anggota tercermin dari keterlibatan anggota dalam proses pengambilan keputusan serta berjalannya fungsi kontrol anggota terhadap roda kepengurusan organisasi.

Uraian tersebut menunjukkan bahwa faktor penentu terlaksananya partisipasi anggota koperasi tergantung pada kemampuan atau potensi sosial dan ekonominya. Dalam penelitian Hermanto faktor sosial yang mempengaruhi partisipasi anggota adalah: (1) kepercayaan anggota terhadap pengurus; (2) adanya rasa memiliki dari anggota; (3) kesesuaian pelayanan; (4) jumlah keluarga dan (5) tingkat pendidikan. Dalam penelitian Muhammad menyebutkan faktor sosial mempengaruhi partisipasi anggota (santri) adalah (1) keterbukaan menerima ide koperasi; (2) komitmen sosial; (3) persepsi mengenai koperasi; (4) kredibilitas pengurus; (5) gaya kepemimpinan pengurus, dan (6) sistem penghargaan (Hermanto, 1991).

Dalam konteks berorganisasi, komitmen didefinisikan sebagai kekuatan relatif individu dalam melibatkan dirinya dengan organisasi) (Mowdey, 1979). Lebih lanjut Mowdey mengungkapkan bahwa komitmen dapat dikarakteristikkan dalam tiga dimensi, yaitu: (1) keyakinan yang kuat akan misi dan tujuan organisasi; (2) kemauan untuk berkorban demi tujuan organisasi dan (3) Memiliki keinginan untuk membina hubungan jangka panjang dengan organisasi. Ketiga dimensi tersebut tidak hanya tampak dalam bentuk perilaku yang nyata namun juga perlu tertanam dalam perasaan. Kaitan antara efektivitas komunikasi dan komitmen terungkap dalam penelitian yang dilakukan oleh Sharma dan Patterson yang menunjukkan adanya faktor-faktor yang mempengaruhi komimen yaitu efektivitas komunikasi, kualitas fungsional, kualitas teknik, dan kepercayaan (Sharma, 1999).

Menurut Drucker (1991) menyatakan bahwa inovasi dihasilkan dari pencarian kesempatan inovasi yang disengaja dan terfokus pada suatu objek tertentu serta bersifat sederhana. Kemudian menurut Pinchot, inovasi dimulai dari hal yang kecil dan 
spesifik, yang berarti melibatkan dana dan orang dalam jumlah yang kecil dan terbatas, serta ditunjukkan untuk mencapai pasar yang kecil dan terbatas. Kemudian menurut Pinchot, inovasi dimulai dari hal yang kecil dan spesifik, yang berarti melibatkan dana dan orang dalam jumlah yang kecil dan terbatas, serta ditunjukkan untuk mencapai pasar yang kecil dan terbatas (Pinchot, 1985).

Selanjutnya menurut Slater menjelaskan adanya ide-ide, gagasan, pendapat dari kegiatan inovasi yang sukses yaitu timbulnya kreativitas yang di bangun dari pasar, yang berorientasi pada budaya perusahaan. Inovasi yang dilakukan oleh organisasi akan memunculkan tingkah laku-tingkah laku baru, oleh karena itu sikap atau tingkah laku yang baru menunjukan adanya kreativitas atau pengembangan yang lebih baik. Ada 4 budaya variabel yang diajukan kedalam kegiatan adalah: (1) partisipasi dalam pengambilan keputusan; (2) dukungan (support); (3) pengembangan diri dan (4) pembagian tugas (Slater, 1990).

\section{Metode Penelitian}

Metode yang digunakan dalam penelitian ini adalah metode deskriptif kuantitatif yaitu penelitian yang bertujuan memuat pemberian (penyandaran) secara sistimatis, faktual, dan akurat mengenai factor-factor populasi tertentu. Teknik pengumpulan data yang digunakan pada penelitian ini adalah daftar pertanyaan/angket sebagai pengumpulan data, metode ini memberikan tanggung jawab kepada responden untuk membaca dan memberi tanggapan atas pertanyaan dari kuesioner dapat memberikan penjelasan mengenai tujuan survei dan pertanyaan yang kurang dipahami oleh responden. Pertanyaan-pertanyaan dalam kuesioner diukur dengan menggunakan skala Likert 1-5 untuk mendapatkan data yang bersifat internal dan diberi skor atau nilai (Sugiyono, 2010). Populasi dalam penelitian ini adalah seluruh Koperasi Syariah yang ada di Kabupaten Lombok Timur yang berjumlah 41 Koperasi Syariah. Sampel dalam penelitian ini adalah menggunakan sampel jenuh. Sampel jenuh adalah sampel yang menggunakan semua populasi menjadi objek penelitian (Ferdinand, 2006). Teknik analisis data yang digunakan dalam penelitian ini adalah Regregi Linier Berganda. Analisis Regresi Linear Berganda digunakan untuk mengukur pengaruh antara lebih dari satu variabel prediktor (variabel bebas) terhadap variabel terikat. 


\section{Pembahasan}

Penelitian ini menggunakan teknik analisis regresi linier berganda, terlebih dahulu yang harus dianalisis adalah uji asumsi klasik agar data yang digunakan benar-benar vaid.

\section{Uji Asumsi Klasik}

Normalitas. Distribusi penyebaran data bersifat normal yang artinya data yang digunakan telah memenuhi normalitas data. Kemudian uji multikolinearitas dimana untuk melihat ada atau tidaknya korelasi (keterkaitan) yang tinggi antara variabel-variabel bebas dalam suatu model regresi linear berganda. Jika ada korelasi yang tinggi di antara variabel-variabel bebasnya, maka hubungan antara variabel bebas terhadap variabel terikatnya menjadi terganggu. Untuk mendeteksi adanya multikolinieritas dalam model regresi linier berganda dapat digunakan nilai variance inflation factor (VIF) dan tolerance (TOL) dengan ketentuan jika nilai VIF melebihi angka 10, maka terjadi multikolinieritas dalam model regresi. Berdasarkan hasil analisis didapat nilai VIF kurang dari 10 yang artinya tidak terjadi Multikolinieritas

Heteroskedastisitas dilakukan dengan metode scatter plot dengan memplotkan nilai ZPRED (nilai prediksi) dengan SRESID (nilai residualnya). Model yang baik didapatkan jika tidak terdapat pola tertentu pada grafik, seperti mengumpul di tengah, menyempit kemudian melebar atau sebaliknya melebar kemudian menyempit. Berdasarkan hasil analisis diperoleh data didapat titik menyebar di bawah serta di atas sumbu Y, dan tidak mempunyai pola yang teratur. Maka dapat disimpulkan variabel bebas di atas tidak terjadi heteroskedastisitas atau bersifat homoskedastisitas.

Uji autokorelasi adalah untuk melihat apakah terjadi korelasi antara suatu periode $\mathrm{t}$ dengan periode sebelumnya (t-1). Secara sederhana adalah bahwa analisis regresi adalah untuk melihat pengaruh antara variabel bebas terhadap variabel terikat, jadi tidak boleh ada korelasi antara observasi dengan data observasi sebelumnya. Persamaan regresi yang baik adalah tidak memiliki masalah autokorelasi. Jika terjadi autokorelasi maka perasamaan tersebut menjadi tidak baik atau tidak layak dipakai prediksi. Ukuran dalam menentukan ada tidaknya masalah autokorelasi dengan uji Durbin-Watson (DW), hasil analisis dapat dilihat bahwa nilai statistik Durbin Watson adalah 1,770. Nilai du pada tabel durbin watson untuk 3 regresor dan $n=41$ adalah 1,660. Dengan demikian nilai statistik durbin watson berada dalam selang $\mathrm{dL} \leq \mathrm{dw} \leq \mathrm{dl}$, maka dapat disimpulkan bahwa data di atas tidak terjadi autokorelasi. 


\section{Analisis Regresi berganda}

1. Korelasi Berganda

Dari hasil analisis regresi, lihat pada output model summary dan disajikan pada tabel 1 sebagai berikut:

Tabel 1. Hasil Analisis Korelasi Berganda

\begin{tabular}{ccc}
\hline $\mathbf{R}$ & R-Square & Adjusted $\mathbf{R}-$ Square \\
\hline 0,725 & 0,565 & 0,537 \\
\hline
\end{tabular}

Berdasarkan tabel 1 di atas diperoleh angka $\mathrm{R}$ sebesar 0,725. Hal ini menunjukkan bahwa terjadi hubungan yang sangat kuat antara partisipasi anggota, komitmen dan kemampuan berinovasi terhadap kinerja koperasi Syariah di Kabupaten Lombok Timur. Berdasarkan tabel 1 di atas diperoleh angka Adjusted R Square sebesar 0,565 atau (56,5\%). Hal ini menunjukkan bahwa presentase sumbangan pengaruh variabel independen (Partisipasi anggota, komitmen dan kemmampuan berinovasi) terhadap variabel dependen (kinerja Koperasi Syariah) sebesar 56,5\%. Atau variasi variabel independen yang digunakan dalam model (Partisipasi anggota, komitmen, dan kemampuan berinovasi) mampu menjelaskan sebesar 56,5\% variasi variabel dependen (Kinerja koperasi syariah). Sedangkan sisanya sebesar 43,5\% dipengaruhi atau dijelaskan oleh variabel lain yang tidak dimasukkan dalam model penelitian ini.

2. Pengujian Hipotesis secara bersama-sama (Simultan)

Dari hasil output analisis regresi dapat diketahui nilai $\mathrm{F}$ seperti pada tabel 2 berikut ini:

Tabel 2. Hasil ANOVA - Uji F

\begin{tabular}{cccccc}
\hline Model & Sum of Squares & Df & Mean Square & Fhitung & Sig. \\
\hline Regresi & 970,640 & 3 & 323,547 & 45,338 & 0,001 \\
Residual & 442,451 & 62 & 7,136 & & \\
Total & 1413,091 & 65 & & & \\
\hline
\end{tabular}
tabel. Dari hasil pengolahan data diketahui bahwa F hitung sebesar 45,338 dan F-tabel pada derajat bebas regresi 3 dan derajat bebas residual 62 serta $\alpha 0,05$ adalah 2,75. F hitung > F tabel $(45,338>2,75)$, maka Ho ditolak, artinya ada pengaruh yang signifikan variabel partisipasi anggota, komitmen dan kemampuan berinovasi secara 
bersama-sama terhadap terhadap Kinerja Koperasi Syariah. Jadi dari kasus ini dapat disimpulkan bahwa variabel partisipasi anggota, komitmen dan kemampuan berinovasi secara bersama-sama terhadap terhadap Kinerja Koperasi Syariah di Kabupaten Lombok Timur. Selain membandingkan nilai $\mathrm{F}$ hitung $\mathrm{n} F$ tabel, dengan membandingkan nilai Sig dengan nilai $\alpha$ yaitu Sig $<\alpha 5 \%(0,001<0,05)$ maka Ho ditolak dan $\mathrm{Ha}$ diterima, artinya variabel Partisipasi, Komitmen dan Kemampuan Berinovasi secara bersama-sama (simultan) mempunyai pengaruh yang signifikan terhadap kinerja Koperasi Syariah Kabupaten Lombok Timur.

3. Pengujian Hipotesis secara sendiri (Parsial)

Hasil analisis regresi output dapat disajikan pada tabel 3 sebagai berikut:

Tabel 3. Hasil Uji t

\begin{tabular}{lcccc}
\hline \multicolumn{1}{c}{ Model } & Unstd. Coeff. & Std. Coeff. & thitung & Sig. \\
\hline Konstanta & $-43,337$ & & $-4,833$ & 0,032 \\
Partisipasi (X1) & 1,038 & 0,042 & 2,252 & 0,004 \\
Komitmen (X2) & 1,227 & 0,134 & 2,802 & 0,003 \\
Kemampuan & 2,078 & 0,135 & 3,809 & 0,002 \\
\hline
\end{tabular}

Berdasarkan tabel 3 di atas, maka dapat dibuat model regresi linier berganda dengan persamaan sebagai berikut:

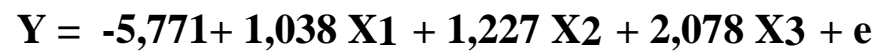

Nilai masing-masing koefisien regresi Variabel Independen dari model regresi linier tersebut memberikan gambaran bahwa:

1. Koefisien Regresi Variabel Partisipasi (X1) sebesar 1,038 menggambarkan bahwa partisipasi anggota mempunyai pengaruh positif dan signifikan terhadap kinerja koperasi syariah di Kabupaten Lombok Timur, artinya dengan semakin besarnya partisipasi anggota maka Kinerja koperasi syariah akan makin meningkat.

2. Koefisien Regresi Variabel Aktivitas komitmen (X2) sebesar 1,227 menggambarkan bahwa komitmen mempunyai pengaruh positif dan signifikan terhadap kinerja koperasi syariah di Kabupaten Lombok Timur, artinya dengan semakin tingginya komitmen maka kinerja koperasi syariah di Kabupaten Lombok Timur semakin meningkat. 
3. Koefisien Regresi Variabel kemampuan berinovasi (X3) sebesar 2,708 menggambarkan bahwa kemampuan berinovasi mempunyai pengaruh positif terhadap kinerja koperasi syariah di Kabupaten Lombok Timur, artinya dengan semakin besarnya kemampuan berinovasi maka kinerja koperasi syariah di Kabupaten Lombok Timur semakin meningkat.

Uji hipotesis secara parsial digunakan untuk mengetahui pengaruh dari masingmasing Variabel Independen terhadap Variabel Dependen. Uji ini dilakukan dengan membandingkan nilai t-hitung dengan nilai t-tabel. Nilai t-hitung dari hasil pengolahan data dengan program SPSS dapat dilihat pada Tabel 3 Hasil Uji t. Hipotesis Statistik yang diajukan untuk Uji t adalah:
Ho:

$$
\begin{aligned}
& \mathrm{b}_{1}=0 \\
& \mathrm{~b}_{2}=0 \\
& \mathrm{~b}_{3}=0
\end{aligned}
$$$$
\text { Ha: }
$$$$
\mathrm{b}_{1} \neq 0
$$$$
\mathrm{b}_{2} \neq 0
$$$$
\mathrm{b}_{3} \neq 0
$$

Untuk memperoleh nilai t-tabel, dapat dilihat pada tabel t, yaitu pada Degrees of Freedom (df) sebesar 41 (df residual pada ANOVA) dan $\alpha=5 \%$ (uji dua arah) maka nilai ttabel sebesar 1,684. Dengan membandingkan nilai t-hitung dengan t-tabel maka dapat disimpulkan bahwa:

1. Variabel partisipasi anggota, yaitu t-hitung $>$ t-tabel atau 2,252 > 1,648 maka Ho ditolak dan hipotesis penelitian diterima, artinya partisipasi anggota mempunyai pengaruh yang signifikan terhadap kinerja koperasi syariah di Kabupaten Lombok Timur.

2. Variabel komitmen, yaitu t-hitung > t-tabel atau 2,802 > 1,684 maka Ho ditolak dan hipotesis penelitian diterima, artinya komitmen mempunyai pengaruh yang signifikan terhadap Kinerja koperasi syariah di Kabupaten Lombok Timur.

3. Variabel kemampuan berinovasi, t-hitung $>$ t-tabel atau 3,809 > 1,684 maka Ho ditolak dan hipotesis penelitian diterima, artinya kemampuan berinovasi mempunyai pengaruh yang signifikan terhadap kinerja koperasi syariah di Kabupaten Lombok Timur.

Berdasarkan hasil analisis standardize coefficient regresi pada Tabel 4.13 dapat diketahui urutan variabel mana yang memiliki pengaruh kinerja koperasi ke (partisipasi 
anggota, komitmen, dan kemampuan berinovasi) paling dominan terhadap kinerja koperasi syariah di Kabupaten Lombok Timur.

Tabel 4. Nilai Standardize Coefficient Hasil Analisis Regresi

\begin{tabular}{lc}
\hline \multicolumn{1}{c}{ Model } & Std. Coeff. \\
\hline Partisipasi angoota (X1) & $0,042(3)$ \\
Komitmen (X2) & $0,134(2)$ \\
Kemampuan Berinovasi (X3) & $0,135(1)$ \\
\hline
\end{tabular}

Tabel 4 menunjukkan bahwa variabel Kemampuan berinovasi (X3) adalah variabel yang paling kuat sebagai pengukur kinerja koperasi syariah di Kabupaten Lombok Timur. Dengan demikian dapat diketahui bahwa responden menyatakan bahwa variabel pendukung terbesar dari kinerja koperasi adalah kemampuan berinovasi. Kemampuan berinovasi berdampak signifikan terhadap arus kinerja koperasi. Peningkatan kinerja koperasi tergambar dari adanya peningkatan kepercayaan anggota dan calon anggota kepada koperasi, sebaliknya penurunan kinerja koperasi terjadi jika kesejahteraan anggota terabaikan. Sementara variabel partisipasi anggota (X1) adalah variabel yang paling lemah sebagai pengukur kinerja koperasi syariah di Kabupaten Lombok Timur. Dengan demikian dapat diketahui bahwa responden menyatakan bahwa variabel pendukung terlemah adalah partisipasi anggota. Partisipasi anggota mencerminkan penerimaan keikutsertaan anggota koperasi dalam kegiatan yang dilakukan koperasi. Secara general, kemampuan berinovasi memungkinkan timbulnya tingkat kepercayaan anggota yang lebih tinggi apabila kinerja perusahaan bagus. Namun jika kinerja perusahaan rendah kepercayaan anggota.

Telah dilakukan analisis data dan pengujian terhadap 4 hipotesis penelitian sesuai modul-modul teoritis yang telah diuraikan pada bab II. Hasil yang diperoleh menunjukkan bahwa semua hipotesis dapat diterima model teoritis telah diuji dan uji asumsi klasi dan mendapatkan hasil yang baik pengujian dan juga menunjukkan hasil yang tidak menyimpang dari yang dihipotesiskan. Penelitian ini mengembangkan 4 hipotesis yang akan dibuktikan dengan data yang diperoleh. Hasil yang diperoleh dari uji masingmasing hipotesis adalah sebagai berikut:

H1: Variabel Partisipasi anggota berpengaruh positif dan signifikan terhadap kinerja koperasi. 
Hasil pengujian hipotesis 1 mendapatkan bahwa nilai t-hitung $>$ t-tabel atau 2,252 > 1,684 Pengujian menujukkan hasil yang signifikan dengan nilai dengan probabilitas = $0,004<0,05 \mathrm{Hal}$ ini berarti Hipotesis 1 diterima. Dengan demikian hasil penelitian ini sesuai dengan penelitian Gunawan Aji (2011), Noor Salaamah (2014), Setiawan (2006), Arrifin (2010). Pengaruh yang positif dan signifikan mencerminkan bahwa semakin baik partisipasi anggota yang dilakukan maka Kinerja koperasi akan semakin baik pula, sedangkan sebaliknya apabila partisipasi anggota semakin buruk maka akan mempengaruhi semakin buruknya Kinerja Koperasi, karena partisipasi anggota dapat menimbulkan rangkaian kegiatan yang berhubungan dengan hak dan kewajiban mereka sebagai pemilik koperasi. Partisipasi anggota dapat diukur dari kesediaan anggota untuk memikul kewajiban dan menjalankan hak anggotanya secara bertanggung jawab.

Kegiatan yang dilaporkan dalam partisipasi anggota adalah keikut sertaan para anggota dalam kegiatan koperasi seperti selalu hadir dalam RAT, partisipasi anggota dalam penanaman modal, partisipasi anggota dalam memanfaatkan pelayanan yang disediakan oleh koperasi dan selalu memberikan ide-ide untuk koperasi serta selalu memberikan sumbahsih yang bermanfaat untuk koperasi. peningkatan partisipasi dapat dilakukan dengan meningkatkan kemamfaatan anggota, meningkatkan kontributif anggota dalam pengambilan keputusan, meningkatkan partisipasi kontributif keuangan.

\section{H2: Variabel Komitmen berpengaruh positif dan signifikan terhadap kinerja} koperasi.

Hasil pengujian hipotesis 2 mendapatkan bahwa nilai t-hitung > t-tabel atau 2,802> 1,684. Pengujian menujukkan hasil yang signifikan dengan nilai dengan probabilitas = $0,003<0,05 \mathrm{Hal}$ ini berarti Hipotesis 2 diterima. Dengan demikian hasil penelitian ini sesuai dengan hasil penelitian yang dilakukan penelitian Gunawan Aji (2011), Noor Salaamah (2014). Pengaruh yang positif dan signifikan mencerminkan bahwa semakin baik komitmen yang dilakukan maka Kinerja koperasi akan semakin baik pula, sedangkan sebaliknya apabila komitmen semakin buruk maka akan mempengaruhi semakin buruknya Kinerja Koperasi, karena komitmen merupakan sangat penting dan JITU (jujur, inovatif, tekun,usaha).

Adapun komitmen anggota sebagai bentuk kepedulian dalam koperasi syariah yaitu; 1). Sadar akan kewajiban (Koperasi telah membantu anggota dalam menyediakan modal untuk mengembangkan usaha atau untuk tujuan konsumtif. Oleh sebab itu 
diperlukan kesadaran anggota untuk mengangsur kewajiban mereka setiap bulannya); 2). Mengikuti aturan dan prosedur Koperasi Kredit. Setiap Koperasi Kredit memiliki kebijakan-kebijakan yang harus dipatuhi oleh anggota demi kelancaran proses administrasi (simpan dan pinjam); 3). Terlibat aktif dalam kegiatan Koperasi Kredit. Anggota merupakan pemegang keputusan tertinggi dalam lembaga koperasi terutama dalam Rapat Anggota Tahunan (RAT) yang diadakan setiap tahun; 4). Memiliki sikap rasa memiliki; 5). Menciptakan hubungan yang erat antar sesama anggota, staf/pegawai, managemen, pengawas dan pengurus. Hubungan yang erat dengan rasa kekeluargaan dapat meningkatkan komunikasi yang baik, agar seluruh permasalahan yang terjadi dapat diatasi secara bersama-sama.

\section{H3: Variabel Kemampuan berinovasi berpengaruh positif dan signifikan terhadap} kinerja koperasi.

Hasil pengujian hipotesis 3 mendapatkan bahwa nilai t-hitung > t-tabel atau 3,809> 1,684. Pengujian menujukkan hasil yang signifikan dengan nilai dengan probabilitas $=$ $0,002<0,05 \mathrm{Hal}$ ini berarti Hipotesis 3 diterima. Dengan demikian hasil penelitian ini sesuai dengan hasil penelitian Gunawan Aji (2011), Noor Salaamah (2014), Anwar Deli \& Adhisyahfitri Evalina Ikhsan (2011). Pengaruh yang positif dan signifikan mencerminkan bahwa semakin baik Kemampuan berinovasi yang dilakukan maka Kinerja koperasi akan semakin baik pula, sedangkan sebaliknya apabila kemampuan berinovasi semakin buruk maka akan mempengaruhi semakin buruknya Kinerja Koperasi. Kemampuan berinovasi mengacu pada pengembangan koperasi yang positif, agar koperasi terus dapat menjalankan aktivitasnya kemampuan anggota didalam berinovasi harus selalu ditingkatkan dalam hal: hak betindak, kemampuan (konpetensi), motivasi untuk berprestasi

\section{H4: Variabel Partisipasi anggota, Komitmen dan Kemampuan Berinovasi bersama-} sama berpengaruh positif dan signifikan terhadap kinerja koperasi.

Hasil pengujian hipotesis 4 mendapatkan bahwa nilai F-hitung > F-tabel atau 8,283 > 2,84. Pengujian menujukkan hasil yang signifikan dengan nilai dengan probabilitas $=0,004<0,05$ Hal ini berarti Hipotesis 4 diterima. Dengan demikian hasil penelitian ini sesuai dengan Gunawan Aji (2011), Noor Salaamah (2014), Anwar Deli \& Adhisyahfitri Evalina Ikhsan (2011). Pengaruh yang positif dan signifikan mencerminkan bahwa secara simultan semakin baik Partisipasi anggota, komitmen dan kemampuan berinovasi yang dilakukan maka Kinerja koperasi akan semakin baik pula, sedangkan 
sebaliknya apabila secara simultan semakin baik Partisipasi anggota, komitmen, dan kemampuan berinovasi semakin buruk maka akan mempengaruhi semakin buruknya Kinerja Koperasi.

Partisipasi anggota, komitmen, kemampuan berinovasi sangat penting dalam meningkatkan kinerja koperasi syariah, jika kinerja koperasi baik maka akan terwujudnya koperasi syariah yang berkwalitas. Taraf partisipas anggota akan meningkat jika terdapat keterbuaan ide, persepsinya dan komitmen yang kuat dari segenap anggota dan pengurus. Oleh karena itu program-program pelatihan perkoperasian merupakan salah satu tumpuan harapan untuk mencapai peningkatan SDM dalam rangka meningkatkan peran aktif anggota koperasi syariah.

Tabel 4.17 Kesimpulan Hipotesis

\begin{tabular}{lll}
\hline H1 & \multicolumn{1}{c}{ Hipotesis } & Hasil Uji \\
\hline H2 & $\begin{array}{l}\text { Variabel partisipasi anggota berpengaruh signifikan } \\
\text { Variabel komitmen berpengaruh signifikan } \\
\text { terhadap kinerja kinerja }\end{array}$ & Diterima \\
H3 & $\begin{array}{l}\text { Variabel kemampuan berinovasi berpengaruh } \\
\text { signifikan terhadap kinerja koperasi } \\
\text { Variabel partisipasi anggota, komitmen dan } \\
\text { kemampuan berinovasi secara bersama-sama } \\
\text { berpengaruh signifikan terhadap kinerja koperasi }\end{array}$ & Diterima \\
& Diterima \\
\hline
\end{tabular}

\section{Kesimpulan}

Penelitian ini mengembangkan hipotesis yang akan dibuktikan dengan data yang diperoleh. Hasil yang diperoleh dari uji masing-masing hipotesis. Variabel Kemampuan berinovasi (X3) adalah variabel yang paling kuat sebagai pengukur kinerja koperasi syariah di Kabupaten Lombok Timur. Sementara variabel Partisipasi Anggota (X1) adalah variabel yang paling lemah. Variabel partisipasi anggota (X1) mempunyai peranan (Ha diterima, H0 ditolak) pada kinerja Koperasi di Kabupaten Lombok Timur. Partisipasi anggota sangat mempengaruhi kinerja koperasi syariah di Kabupaten Lombok Timur. Semakin tinggi partisipasi anggota maka semakin tinggi pula kinerja koperasi syariah di Kabupaten Lombok Timur yang kinerjanya diukur menggunakan kesejahteraan anggota. Variabel komitmen (X2) mempunyai peranan (Ha diterima, H0 ditolak) pada kinerja koperasi syariah di Kabupaten Lombok Timur. Komitmen sangat mempengaruhi kinerja 
Koperasi syariah di Kabupaten Lombok Timur. Semakin tinggi komitmen maka akan semakin tinggi pula kinerja koperasi syariah di Kabupaten Lombok Timur. Variabel kemampuan berinovasi (X3) mempunyai peranan (Ha diterima, H0 ditolak) pada kinerja koperasi syariah di Kabupaten Lombok Timur. Hasil ini menunjukkan bahwa kemampuan berinovasi yang dilakukan koperasi syariah di Kabupaten Lombok Timur sangat penting artinya bagi kelangsungan hidup koperasi, hal ini dapat dilihat keterbukaan para pengurus koperasi dalam menampung ide-ide yang diberikan oleh anggotanyya. Kemampuan berinovasi ini merupakan variabel yang paling kuat mempengaruhi kinerja koperasi syariah di Kabupaten Lombok Timur.

\section{Daftar Rujukan}

Aji, G. (2011). Faktor-Faktor yang Mempengaruhi Kinerja Koperasi Pondok Pesantren. Walisongo: Jurnal Penelitian Sosial Keagamaan, 19(1), 231-260.

Anwar Deli \& Adhisyahfitri Evalina Ikhsan, (2011). Analisis Kinerja Koperasi di Kota Banda Aceh dan Aceh Besar, Jurnal Sains Riset, 1(2), 71-78.

Djamhari, Choirul. (1985). Ke Arah Pemahaman Bangun Perusahaan Koperasi (Antologi Esai). Jakarta: Balitbang Koperasi, Departemen Koperasi.

Drucker, P.F. (1991). Inovasi dan Kewiraswastaan, (Terjemahan Naib, R., Jakarta: Erlangga.

Ferdinand, Augusty. (2006). Metodelogi Penelitian Manajemen. Semarang: Indoprint.

Hanel, Alfred. (1985): Basic Aspect of Cooperative Organization and Polices for their Promotion in Developing Countries, Bandung: Bandung: Universitas Padjadjaran dan Marbug University.

Helfert, Erick A. (1996). Prinsip-prinsip Manajemen Keuangan I, Jakarta: Salemba Empat.

Hermanto, Bambang. (1991). Faktor-faktor yang Mempengaruhi Partisipasi Anggota dan Hubungannya dengan Keberhasilan Koperasi di Minahasa. Disertasi. Bandung, Universitas Padjajaran.

Mowday, R. T., Steers, R. M., \& Porter, L. W. (1979). The measurement of organizational commitment. Journal of vocational behavior, 14(2), 224-247.

Mulyadi. (2001). Sistem Akuntansi, Yogyakarta: BP STIE YKPN.

Narver, J. C., \& Slater, S. F. (1990). The effect of a market orientation on business profitability. Journal of marketing, 54(4), 20-35.

Pinchot, G. (1985). Intrapreneuring. New York: Harper \& Row Publisher.

Sharma, N., \& Patterson, P. G. (1999). The impact of communication effectiveness and service quality on relationship commitment in consumer, professional services. Journal of services marketing, 13(2), 151-170.

Sholihin, Ahmad Ifham. (2010). Pedoman Umum Lembaga Keuangan Syariah. Jakarta: Gramedia. 
Vol. 5 No. 1, Desember 2018, hal. 15-30

Sitio, Arifin. (2001). Koperasi Teori dan Praktek. Jakarta: Erlangga

Sugiyono, (2010). Metode Penelitian Kuantitatif Kualitatifdan R\&B. Bandung: Alfabeta

Sumardi, (2007). Analisis Pengaruh Budaya Organisasi dan Gaya Kepemimpinan Terhadap Kepuasan Kerja dan Kinerja Karyawan (Studi Empiris: Karyawan Administratif Universitas Semarang). Tesis. Semarang: Universitas Semarang.

Tambunan, Tulus. (2012). Usaha Mikro Kecil dan Menengah di Indonesia. Jakarta: LP3ES

Undang-undang Nomor 25 tahun 1992 tentang Perkoperasian. Jakarta: Departemen Koperasi. 